Informasi - ISSN (p) 0126-0650; ISSN (e) 2502-3837

Vol. 5o, No. 1 (2020), pp. 15-29, doi: http://doi.org/10.21831/informasi.v50i1. 30174

\title{
Satirical political communication 2019 Indonesia's presidential election on social media
}

\author{
Anang Sujoko \\ Department Communication, Faculty of Social and Political Science, \\ Universitas Brawijaya, Indonesia \\ anangsujoko@ub.ac.id
}

Article History: Received 2020-02-12, Revised 2020-07-20, Published 2020-07-30

\begin{abstract}
This study aims to reveal how satirical political communication by three kinds of social media accounts that have a large followers in Indonesia in the theme of the 2019 Presidential Election. Using Van Dijk's critical discourse analysis model, this study uncovered the discourse that underlies criticism of candidates for presidential and vicepresidential candidates 2019 on Youtube, Facebook, and Twitter. The research found Prabowo vs. Jokowi's rap battle by skinnyindonesia24, nurhadi_aldo's Instagram account, and \#2019GantiPresiden as the most prominent accounts that distributed satire political communication. The owner of a social media account produces messages based on a lively and controversial issue on social media. Account \#2019GantiPresiden even tends to criticize incumbent candidates because they see that the mainstream media does not do its role. Nurhadi_aldo's account manager sees sharp polarization between supporters of two pairs and tends to criticize controversial incumbent candidate programs. Skinnyindonesia24 reduces the polarization that is getting stronger by more balanced criticizing the competition of two presidential candidates through rap music. This study convinces that the nature of satirical political communication work efficiently because the content does not cross agreed-upon political boundaries and cultural spaces.
\end{abstract}

Fokus penelitian ini ada pada komunikasi politikyang terjadi di platform media sosial selama pemilihan presiden 2019 di Indonesia. Menggunakan model analisis wacana kritis Van Dijk, penelitian ini mengungkap wacana yang mendasari kritik terhadap calon pasangan presiden dan wakil presiden 2019 di Facebook, Twitter, dan Youtube. Hasil penelitian menemukan pertarungan rap Prabowo vs Jokowi oleh skinnyindonesia24, akun Instagram nurhadi_aldo, dan \#2019GantiPresiden sebagai akun paling menonjol yang mendistribusikan komunikasi politik sindiran. Sindiran dan humor dapat menjadi bentuk komunikasi politik bagi publik untuk mengritisi kandidat dengan aman. Pemilik akun media sosial memproduksi pesan berdasarkan isu yang ramai dan kontroversial di media sosial. Akun \#2019GantiPresiden bahkan cenderung mengritisi kandidat petahana karena melihat tidak netralnya media mainstream dalam memberitakan para kandidat. Pengelola akun nurhadi_aldo melihat 
polarisasi yang tajam di antara pendukung dua pasangan dan cenderung mengritisi program-program kandidat petahana yang kontroversi. Uskinnyindonesia24 meredam polarisasi yang semakin kuat dengan lebih seimbang mengritisi persaingan dua kandidat calon presiden melalui musik rap. Studi ini menunjukkan bahwa sifat komunikasi politik satir memungkinkan untuk bekerja secara efisien karena konten dan kemasan ide tidak melewati batas politik yang disepakati dan ruang budaya.

Keywords: Political Communication, Social Media, Presidential Election 2019, Political Satire

\section{INTRODUCTION}

This study explores the topic of satirical political communication in social media Indonesian politics, especially in the momentum of the 2019 presidential election. The focus of the study on satirical political communication in the new media during the 2019 presidential election with a variety of satire objectives distinguishes from the study of political communication that has often discussed satirical political communication in the mainstream media (Cutbirth, 2011), to satirize public institutions and elected public officials (Cutbirth, 2011) and "discrediting those in authority" (Cameron, 1993). Satire has been seen as working to reframe political discourse that takes place in the mainstream media and popular culture about things that are very important for the functioning of democracy properly, starting from election results, ethical behavior of companies and governments (Reilly, 2013). This study contextualizes the ideas beyond what has been done, namely satirical political communication in new media with a variety of targets outside the satire habits in the mainstream media.

Several reasons underlying the importance of building knowledge on the topic of satirical political communication in new media are motivated, namely empirical and theoretical reasons - first, practical reasons. It fills the new media ahead of and during the 2019 presidential election. This phenomenon shows that satirical political communication significantly develops when therearemomentsof thepoliticalyearthrough new media. During the 2019 presidential election campaign, what mainstream media aired will be followed in new media. Besides being filled with mainstream media content, satirical political communication with various packaging variants also enliven the discussion on new media and it can boost the issues (Boukes, 2019). Furthermore, in the context of the 2019 presidential election, satire political communication emerged with various satire targets.

The development of satirical political communication is inseparable from the existence of new media. This media has become a space that allows expressing opinions for Indonesian citizens not only as listeners as their position when dealing with mainstream media. According to Jenkins, Ford \& Green (2013), this change in the position of individuals has changed since the advent of web 2.0, where the participatory culture that initially individuals only as passive content consumers changes and functions in a collaborative network to actively and critically evaluate, reshape and spread media content.

At least two things cause the rapid acceptance of new media to engage in satirical political communication: the nature of the mainstream media itself and the nature of new media with the impact of media politics. From the nature of the mainstream media, It places the colors of the country as spectators, without giving a choice to criticize directly. If the news content is unliked, inevitably listen and see what is reported without being able to directly criticize the media if the audiences do not like the news. Whereas in new media, the public or in its terms is netizens can criticize directly to the new media account if they do not like the content. This interactivity is because the new media provides two-way communication facilities (Louw, 2007). The new media has changed the position of society in interaction with formal 
power structures, especially in the process of political communication. Originally, Indonesian citizens were only listeners and viewers of ideas, the information conveyed by formal power through the mainstream media now has the opportunity of reciprocal communication with power structures through new media, even as creators.

The second cause is because of the saturation of the mainstream media that is unable to function (as a result of media politics) as a true (read: autonomous) media that preaches news without having to be adjusted to the interests of the media channel owners or in the term Tapsell (2017) referred to as "conglomerates digital." The mainstream media is increasingly faceless when digital conglomerates (read: oligarchs) have an affair with political actors. Democracy is unable to stem the strength of the duet of these two actors. As the paradox of democracy, Indonesia arranges its political life into a democracy with the hope of treating the disease of the New Order, namely the concentration of power and wealth on a handful of people so that it does not spread worse and hopes of recovery are healed. Instead of oligarchs shrinking, precisely what happens is democracy becomes a condition that fosters the practice of concentration of power and wealth of oligarchs who had grown in the New Order era (Tapsell, 2017).

The control of the Indonesian media channel by the oligarchs and political actors once attacked Basuki Tjahaja Purnama, or popularly known as Ahok or BTP. The oligarchs who own national media companies preach Ahok as a rude, unstable, untrustworthy person (Tapsell, 2017). Coverage in such personal attacking media explains how the mainstream media is unable to carry out its actual functions. Ahok took advantage of social media by uploading his raw video footage on YouTube about his political activities as the Governor of DKI, starting with visits to government offices, while publicly reprimanding lazy officials. What Ahok did was to respond to the news about him in the mainstream media. Uploading videos to Youtube with a purpose, which is so viewers can witness his personality as a whole (Tapsell, 2017). From what Ahok showed, new media such as Youtube became the choice that gave ample space to carry out political communication without cutting content, and as a medium of resistance. Similar evidence happened in Spain where internet can provide alternative medium to counter majority hegemonic on mainstream media (Sampedro \& Avidad, 2018).

The second reason is the theoretical reason. Communication scientists have placed new media as having the possibility of changing and generating communication, that is, bringing about new forms of politics and communication culture. However, Neuman (1991) doubts that new media will easily arouse citizen participation. Neuman argues, introducing new media technology will not necessarily change either mass psychology or commercial logic that supports United States communication. According to him, the new media has not revived communication, values, and lifestyles of small and rural cities; not giving birth to new participatory democracy or producing new citizens who are actively involved; not yet over spin-doctoring and steering mass hearings; also does not produce better journalism.

Neuman's worries have not been proven right. For example, a study conducted by Cutbirth (2011) on political satire in America shows that political satire has become part of the journalism strategy (read: political communication) in the mainstream media. Likewise, the Indonesian case shows the emergence of a new political and cultural form of communication from the grassroots through new media. Much of the content of political communication that appears in new media is in the form of communication content in general with dense, loud language and a new style of political communication, namely political satire. Although in Indonesia, political satire is not a new phenomenon, political satire itself has been broadcast in mainstream media.

In a study of German satirists, Bessant (2016) revealed that satire or humorous 
political communication on social media arises when they feel marginalized by the mainstream media who tend to ignore criticisms and even do not give in to other opinions that develop in society. Revealed that satire or humorous political communication on social media arises when they feel marginalized by the mainstream media who tend to ignore criticisms and even do not give in to other opinions that develop in society (Utomo, 2015).

The hubbub of the emergence of satirical political communication in the new media during the 2019 presidential election, as described above, indicates that digital democracy has been working in Indonesia. Surely this is good progress for Indonesian democracy, and indeed for the journey of Indonesian Reform. However, digital democracy in Indonesia does not mean free space without limits for expression. Indonesia, through the Information and Electronic Transaction Law, has given a limit to communicate one of them in new media, especially related to hate speech. It is common for citizens who carry out political communication in the new media to lead to criminal matters. The experience of democracy in Athens shows that this form of comedy communication is said to have triggered political conflict between factions. They compete with each other's political agenda, namely, through disguised caricatures, parody with poets through their texts reveals and triggers political conflicts (Sidwell, 2009).

In short, the new media empirically in Indonesia has aroused political communication and gave rise to a new communication culture; however, this condition has only been seen from two sides. First, in terms of theory about the acceptance of satire as a form of political communication, which has gained a lot of interest (Utomo, 2015). Second, the presence of new media can support political communication activities. From the reading by the researchers, not many people see the communication and satire content that fills new media that causes conflict in their communities.

\section{LITERATURE REVIEW}

\section{a. Fundamental Ideas of Political Communication}

Lasswell raised the idea of communication. He defines communication is about "who says what, in with channels, to whom, with what effect"(Sapienza et al., 2015). The definition of communication is the result of Lasswell's interest in the propaganda of the two world wars, which then resulted in a study around the communicators' motives and key symbols that became the message (Efriza \& Indrawan, 2018).

Furthermore, Jamieson and Kenski (2017, 3) define political communication as "making sense of symbolic exchanges about the shared exercise of power" and "the presentation and interpretation of information, messages or signals with potential consequences for the exercise of shared power." These two figures do not limit who can carry out political communication. In essence, the basic idea of political communication is how messages can influence the distribution and use of power that is spread in society, not lies in the communicator - but the communicator is also essential -. As Lasswell emphasized, message symbols become crucial

In general, political communication can be classified into various forms depending on the activity and purpose. Political communication, according to Arifin (2011) there are several forms. First, rhetoric has been initially used in debates in the courtroom to influence each other so that it is interpersonal activities. It developed into a mass communication activity that is addressing the public. Second, political agitation operates to awaken people to a political movement, both oral and written, by stimulating and arousing people's emotions and starting with how to make a contradiction in society and move the public to oppose the reality of life experienced to cause anxiety among the masses. Third, propagandists are people who carry out propaganda capable of reaching a larger collective audience, usually done by politicians or political party cadres who can make suggestions to the public and create an atmosphere that is susceptible to 
suggestion. Fourth, Public Relations Politics. The aim is to create a trusting, harmonious, open, or accommodating relationship between politicians, professionals, or activists and the public. Fifth, a political campaign is a form of political communication carried out by people or groups in a particular time to obtain and strengthen political support from the voters.

The characteristics of campaign are a transparent source of implementation, bound and constrained implementation time, nature of ideas open to public debate, strict, diverse and specific objectives, ways of receiving voluntary and persuasive messages, mode of action governed by rules and codes of ethics, and nature of interests that take into account interests both sides. Sixth, political lobbying. In a political lobby, the influence of a politician's personality is very influential such as his competence, mastery of problems, and charisma. Seventh, mass media, as an extension of the five human senses and as a media message in terms of political messages to gain influence, powerauthority, shape and change public opinion or support and political imagery, to broader audience or that cannot be reached by other forms of communication

\section{b. Mainstream Communication Media that Provides Exclusivity vs. New Media}

Thebasicidea of political communication that does not limit the communicator or messenger is inversely proportional to the reality in the mainstream media. Most political communicators in the mainstream media are those who are members of an alliance of interests. As a result, what happens in the mainstream news is news that is very dependent on the alignments of the interests of the mainstream media companies. Alignment in the mainstream media because the media has economic and political interests to continue to maintain a stable situation for the sustainability and development of its media business (Efriza \& Indrawan, 2018). The needs of these mainstream media entrepreneurs meet the needs of the political communication media of political actors. An alliance between mainstream media entrepreneurs and political actors makes it easy for mainstream media entrepreneurs to conduct media conglomerations and media oligarchies. The result is that access to mainstream media is difficult to penetrate by people who do not have the same interests as the media, and by citizens who want to voice their interests.

During this time, the mainstream media has the role of delivering a message. There are several technics of the mainstream media for delivering messages. First, Sound Bite, in the mainstream, media often limited by a relatively limited time. Therefore, journalists often use this soundbite technique to deliver the news. News delivered is usually not entirely displayed, but journalists only include pieces of news that are considered necessary (Efriza \& Indrawan, 2018). Second, Strength of Text, The power of text refers to the message of communication itself. The strength of this communication message depends on the communicator constructing reality into a message that can reflect the interests of the communicator. The strength of this text shows the tendency of interest when getting media support. Third, the language of hyperbole politicians. Political communication, according to Brian McNair in (Efriza \& Indrawan, 2018) aims to understand government, political parties and encourage voting in elections. Therefore, politicians are often required to use hyperbole languages, but they are precise and delivered at the right time, regardless of the language processed by a team of experts or ideas from politicians themselves (Efriza \& Indrawan, 2018). Fourth, the role of mass media. Communication depends on what media is used (in with channel). The results of the study of Efriza and Indrawan (2018) in the era of modern power, the media are no longer part of politics but play a central role in power. In Banten regional election 2017, governor candidates competed to promote their self on mainstream media. P, Achmad Nasrudin (2016) questioned the independence and objectivity of the media in politicaleconomoy of media. 
The exclusivity of the mainstream media is the reason for new media as alternative and favorite media for citizens to voice their ideas. In fact, according to Tapsell (2017), digital media is used by individuals and collectives by citizens to ward off, rival, or disrupt the dominant mainstream media oligarchic content. Bradshaw, Howard, Kollanyi, \& Neudert (2020) find out that the use of media, including new media, tends to increase during election because of amplifier account. In sames cases the role of amplifier accounts on new media affect the increasing of the polarization and conspiracy content. We use three different new media platforms to enrich research findings and according to Bode and Vraga $(2017,2)$ in hybrid media era, "focus on single platforms can ignore a greal deal".

\section{c. Political Satire in New Media: Popular Strategies Talking about Politics}

The use of satire in journalism (political communication activities) has been going on for a long time in the mainstream media in America, although it makes the boundaries between news and entertainment blurred (Cutbirth, 2011). It has become a part of American life. The political satire aims to question the logic and practice of journalism, politicians, and public institutions and elected public officials. Similar to Cutbirth (2011) and Cameron (1993) in America targets satire comedy on television is public institutions. Furthermore, Cameron (1993) asserted political satire as a means of describing those in authority. Further, Reilly (2013) says satire is used to re-ask political discourse for the functioning of a functional democracy, questioning about the future results of elections related to the ethical behavior of companies with the government. Then, how can satire be practiced in mainstream media?.

The American case shows there is protection against the press and speech by both journalists and satirists (Cutbirth, 2011). Besides, the acceptance of satire in America is due to changes in media technology and acute economic uncertainty hitting traditional news companies at a time when American society needs a credible voice to challengean institution they believe in failing. Furthermore, now in its development, mass communication competes with increasingly diverse narrative groups, including political satire (Cutbirth, 2011).

The results of Reilly's (2013) study of new media provide satirical political space to gain complete public access. According to Thai (2014) political satire is more than limited to what is called humor, and satire provides a tool - giving the recipient the freedom to use it or not. In other words, political satire accepts criticism of the content delivered. The satire matches the nature of the new media, which does not distance the explorers of political talks on social media from the message makers. Departing from the nature of political satire and the nature of new media, as mentioned above, met with the stigma of politics as a substantial and tendious subject of discussion, facilitating the acceptance of political satire in new media as an alternative to discuss politics. Meanwhile, satire can be packaged into pamphlets, novels, poems, caricatures, films, songs, and memes (Plevriti, 2013).

Satire is anact of political communication that results in laughter, and the resulting laughter signifies that political alliances have been successfully beaten (read: quipped) (Cutbirth, 2011). Satire objects include individuals, institutions, or countries. Satirical narratives are complex constructs that evoke responses such as anger, ridicule, entertainment, and comfort. Meanwhile, to read satire cannot only be done by assessing theoutside but must read the implied message from the satire (Cutbirth, 2011). Following is an example of satire and meaning of satire done by Jonathan Swift (Irish satirist) as quoted by Cutbirth:

"When Jonathan Swift suggested: "A young healthy child well nursed, is, at a year old, a most delicious nourishing and wholesome food, whether stewed, roasted, baked, or boiled..." he was not advocating cannibalism or infanticide. He was taking aim at callous bureaucratic British authority and the toll it had taken 
on the Irish people and their country's economy."

There are two satire genres commonly used by Swift, namely Juvenalian Satire and Horatian Satire. First, Juvenalian satire, according to M.H. Abrams (In Cutbirth, 2011) is a speaker who is a severe moralist who uses an elegant public style to denounce ridiculous and dangerous representatives. Juvenalian satire is dark, sarcastic, and full of anger. Second, Horatian Satire displays intelligent, polite, and more tolerant characters to the world. Speakers of the satire genre Horatian aim more at entertainment than anger. This genre is more fun, seductive, and uses mild language, gentle parody to criticize some social representatives or political situations. Comedy stand-ups include the Horation genre.

In delivering satire, there are three forms of delivery, namely irony, sarcasm, and parody. The irony is about pretense; for example, Stephen Colbert pretends to defend a politician that he never agreed with. He mimics their arguments and tone of voice to show how ridiculous they are, whereas parody/spoof is done by imitating someone or something to make fun of and is intended only to entertain and make people laugh. The presence of words or sentences that deviate from the facts and do not touch the object being twisted is a characteristic of parody next, sarcasm. In political satire, the form of sarcasm uses harsh sentences.

\section{d. Critical Discourse Analysis of Teun A. Van Dijk Model}

Text is the result of a production process involving various elements, both text producers, and the social context underlies the process. The text in this study shows how people, including social media accounts, are trying to manipulate messages to achieve their goals. Manipulation of the text can reveal how domination and power abuse (Van Dijk, 2006). He mentions this process with social cognition Van Dijk (1993). Thus, in the analysis of critical discourse, to understand the text can not only analyze the text but must understand the other microelements.
The text in this study is interpreted as a message poured into social media.

Furthermore, not all of the issues contained in the text can be examined in the Critical Discourse Analysis (CDA) research method. In general, CDAs must meet the following criteria; focus on social or political issues and explain the structure of discourse also explain their social interactions. In other words, CDA focuses on the way the structure of discourse enforces, confirms, legitimates, reproduces, or challenges relationships of abuse of power in society (Van Dijk, 1993).

\section{METHODS}

This study is a qualitative study, which explains the phenomenon of the use of figures of speech in political communication in the 2019 Presidential Election in Indonesia. As said by Neuman (2013) that a qualitative approach explains social phenomena indepth and comprehensively based on their natural settings or actions of social meaning. Then, this study uses Van Dijk's model of critical discourse analysis techniques to answer the problem formulation. This research uses Facebook, Instagram, and Youtube platforms because they have the potential to obscure the different roles that occur between producers and consumers in the media industry. So far, the producers of messages in mass communication are the media industry and the public or audience as consumers. But with the latest developments in communication technology, social media platforms, the public can become producers of content that is user-created content.

The social and political problems that emerged ahead of the 2019 presidential election, namely the failure of Jokowi's performance issues, become the most data criteria in this research. Besides, the selection of accounts that consistently criticizes the government, or candidate and has many followers and topics raised in cyberspace. The Instagram account (IG) skinnyindonesia24, which raised the Prabowovs. Jokowi rap battle video, currently has 1.8 million subscribers, and more than 16 million accounts have watched rap battle videos. Nurhadi-Aldo or 
Dildo Instagram account.

From the selected data, researchers conducted a critical analysis of the message content, translating the social context of words, and knowing social cognition by conducting imaginary interviews with account holders (Van Dijk, 1993).

\section{RESULTS AND DISCUSSION}

\section{a. Satirical Political Communication Ideas and Packaging in New Media in 2019 Presidential Election}

The journey of Indonesia's Reformation was marked by the opening of the right to freedom of opinion and expression. Interestingly, these rights went hand in hand with the development of new communication media and followed by the regulation of freedom of opinion and expression, namely Law Number 11 of 2008, which was changed to the Law on Information and Electronic Transactions (ITE) Number 19 of 2016. Writing in this chapter discusses how ideas and packaging of political communication and satire in the new media in the 2019 presidential election are already under the rules of the ITE Law. Indonesia's political situation is a context that cannot be ignored in discussing ideas and packaging of political communication and satire created in new media. Why is it important? Recalling information from Damar Juniarto, Regional Coordinator Safenet stressed that: "Since the ITE Law was first enacted in 2008, it has taken many victims. Most victims were charged with ITE Law, especially article 27 paragraph (3) and Article 28 paragraph (2). "From Safenet's records up to 31 October 2018, there were 381 victims who were ensnared by the ITE Law, and as many as 90\% were entangled in the ITE Law related to accusations of defamation and hate speech. That is, in freedom of opinion and expression in the new media in the 2019 presidential election, there is a legal and political structure that surrounds it, which cannot be avoided just like that. Of course, this situation will not affect the variety of content, and the packaging of expressions and opinions, especially in new media.

\section{b. Political Communication which became a Legal Case During the 2019 Presidential Election}

In the activities of opinion and expression in the Reformation Era it is not borderless. ITE Law is a form of guarding boundaries mutually agreed by the Government and the Parliament. In 2018, exactly two weeks after the determination of participants for the presidential and vice presidential candidates on September 20, 2018, the reporting of hoak cases by the police began the journey of the 2019 presidential election with reported Ratna Sarumpaet. He works as a capital artist. The alleged article is an article about hate speech, namely article 28 paragraph 2 of the ITE Law and articles 14-15 of Law Number 1 of 1947. Ratna Sarumpaet was reported with violations of content distributed through new media on Facebook and Twitter. The long time of this case, finally met the verdict in July 2019 with sentenced to 2 (two) years in prison for being proven guilty according to article 14 paragraph (1) of Law Number 1 of 1947 namely to cause trouble because of the lies committed, and article 28 paragraph 2 (Marison, 2019).

In general, the activities of opinion and expression in new media, as Safenet analyzes, are entangled in Article 27 paragraph (3) and Article 28 paragraph (2) of the ITE Law. Article 27 paragraph 3 reads to prohibit anyone intentionally and without the right to distributeand/ortransmitand/or makeaccess to Electronic Information and/or Electronic Documents that have content of defamation and/or defamation; Article 28 paragraph (2) reads, every person intentionally and without the right to disseminate information intended to incite hatred or hostility of certain individuals and/or groups based on SARA. While seen from the cases that occur as recorded, the new media used are Twitter (1 account), Instagram (3 accounts), Facebook (6 accounts), YouTube (3 accounts), four online media/UGC, WhatsApp (2 accounts).

As with Safenet's documentation, there were 12 cases of netizens caught in the ITE Law that coincided with the election campaign period, and continued to grow after the 
announcement of the presidential election results. If mapped from the case story, the ITE Law during the presidential election does not only ensnare communication activities in new media relating to the holding of the presidential election, but also relates to public services, local government officials, police professionalism, and social problems in the community.

Meanwhile, if you look at neighboring countries, it is not only law in Indonesia that can impose limitations on freedom of opinion and expression. Countries in Asia such as the Philippines, Cambodia, Malaysia, Myanmar, Singapore, Thailand and Vietnam also have restrictions. Safenet's documentation explains the case at the end of 2018 in Singapore. Singapore's pro-democracy groups oversee cases of digital rights violations (curb expression on the internet, harassment of family members, attacks on electronic devices) an editor of The Citizen Online website Terry $\mathrm{Xu}$, Willy Sum (writer), and Facebook user Leong Sze Hian (Mengecam, 2019). Then in Singapore in 2015, a teenage blogger, Amos Yee uploaded a video titled "Le Kuan Yew is finally dead" which lasted eight minutes containing criticism of Christianity and the late former Prime Minister Lee Kuan Yew. Case details from the video as quoted from Safenet are as follows:

"The video says the founder of Singapore is like a dictator like Mao Zedong, Joseph Stalin and even Adolf Hitler. The basis on which the authorities charged Yee with his negative statements about Christianity and the spread of obscene cartoons. The cartoon depicts Lee Kuan Yew having sex with former British Prime Minister Margaret Thatcher. The police received many complaints from various parties who felt offended because the cartoon appeared only a few days after Lee Kuan Yew died, March 29 last" (Juniarto, 2019).

\section{c. Satire Politics On Youtube}

Nearing one week from the 2019 presidential election day, on April 8 2019, a rap battle genre video from the skinnyindonesian youtube channel24 received the most attention from the public. The video content is related to the Indonesian president and vice presidential candidate pair 2019. The video with a duration of $0: 53$ seconds is entitled Prabowo VS Jokowi-Epic Rap Battles of Presidency. Within one day after being uploaded on April 8, 2019, it managed to occupy the top position of Youtube trending, and until July 17, 2019 it had been watched 36,626,163 times (Adytia, 2019).

Prabowo VS Jokowi- Epic Rap Battles of Presidency consists of two versions. The first version aired on July 2, 2014. In the first version, not enough people watched videos by Andovi da Lopez and Jovial da Lopez. The two videos are the work of Da Lopez Entertainment Production under the name youtube skinyindonesian24. The executive Produser is Andovi da Lopez who also plays Jokowi and Jovial da Lopez who plays Prabowo. The first version of the video until July 21, 2019 or about four years just watched 4,778,705 times. Why are only a few watching? This can at least be explained by two conditions. First, the full use of English from beginning to end in the 2014 version of rap battle can be one of the explanations. Secondly, is the number of social media users in Indonesia, which has not been as large as 2019. Data shows the number of media users continues to increase. At least, the results of Hootsuite Wearesocial research noted that in 2014 there were 1.9 billion social media accounts, and in 2018 there were 3.8 billion accounts.

The lyrics from the Prabowo vs Jokowi rap battle video content version 2019 were made within a period of six days. Content is made from observations of the political situation during the presidential election. The course of the debate candidate organized by KPU is the main material. For the 2019 rap battle video content, these brothers used the first to second debates.

The rap battle video was inspired by the youtube channel from the United States, Epic Rap Battles of History (ERB). The composers in the channel are Peter Shukoff (Nice Peter), Lloyd Ahlquist, Dave McCary, and Maker 
Studio. They began pioneering the channel on September 26, 2010. The concept of the channel show is a rap battle, which is to play two famous figures from history and pop culture and pitting rap between the two figures.

The story of the Indonesian election which is packaged in the form of a video with the 2019 rap battle genre by the sisters, is claimed as a work aimed at entertainment, and is their way as a YouTuber to tell about the upcoming elections in Indonesia.

"We recognize completely that this format is theirs and we are merely using this format as a medium in which we as YouTubers can share the story of the upcoming elections in Indonesia. We mean no violations of intellectual property and we are merely doing this for entertainment purposes. Thank you very much to the guys who did the original show. And as for the video it self, this is a fun video, not to be taken seriously by anyone, particularly, Indonesians. Please enjoy and may we have an amazing election process on the 17th of April 2019. This is by no means a political campaign of any sort."

If you look at the work of Rap battle in the article "How to Rap Battle and Win-Full Guide", it is the same as the comedian who tells jokes, especially in the first line of rap. What distinguishes it from jokes is that in rap, rhyme schemes and rap styles are needed, using words that have a double meaning to be interesting.

\section{d. From Asking For Approval to Airing to Accusations and Appreciation}

Concerns about the existence of legal resistance in publishing opinions turned out to be still a story in the Reformation Era. There was an interesting story about the sisters in their confession on the Rosi Kompas TV show on April 11, 2019. Before the video became public consumption, the brothers had asked permission from their mother. However, the Mom suggested not to be published. The video continues to be published with confidence in a changing era. Jovial Da Lopez assured his mother:
"Mom, this era is already different, if young people do not dare to criticize the conditions in our environment and social, who will criticize, but yes Ando remains rather afraid.)

Even in the comments column, there are concerns about how the fate the brothers, if the work like rap battle appears in the New Order era.

In addition to concerns, there are allegations of video maker siding with one of the participants in the 2019 presidential election. Some think that the siblings are Prabowo's supporters, on the other hand they are accused of supporting Joko Widodo. However, there are also those who appreciate the work of these brothers, one of them is because the rap battle video of Prabowo Vs Jokowi made them give a look to netizens who have the opportunity to abstain because they are confused about determining the choice.

The siblings claimed the rap battle video also aimed to educate netizens to not be too fanatical about one of the camps. As far as they are observing, the people supporting the presidential candidates tend to deny the advantages of other candidates. Jovial Da Lopez (2019) said what he observed that:

"In fact, we are rather annoyed with some people who are very vocal on one thing, that's a problem. Believe in our stance we may be vocal. Only sometimes when we are vocal about one thing, we turn off the kindness of others. Meanwhile, if we elect a president or anyone who will lead the country in the next 5 years, we must really consider what vision and mission they have. Do not because we are blind to one candidate, whatever the other candidate says we turn off, we do not want to hear, we do not want anything. Well I and Andovi, really just for, guys, there are two people, you guys, and you choose the best for you".

12 days after the rap battle video was uploaded precisely on April 24, 2019, Andovi Da Lopez (2019) emphasized the purpose of the rap battle they made. In the closing sentence of the video the rap battle's intent 
was made not to divide the camp, but to reemphasize the differences were important and given the interests of the state.

\section{e. Satire Politics on Instagram}

In addition to Youtube, from Instagram as new media there is a political satire that was also viral in the 2019 presidential election, from the account of a fictitious candidate pair (@nurhadi_aldo). Not only on Instagram, has Nurhadi Aldo's political satire also appeared on Facebook and Twitter. The pair of fictitious presidential and vice presidential candidates in the account are Nurhadi and Aldo. Nurhadi was constructed as a fictitious candidate. In his daily life is a masseuse in Kudus and Aldo regency as fictitious running mate is a fictional character whose face is a combination of several people designed in such a way by eight young men. The BBC.com search results initiated the ideas of fictitious presidential and vice presidential candidates are eight young men spread across Indonesia with an age range of 17 to 23 years who do not want to be revealed.

Theidea for the formation of the nurhadi aldo account is the hot 2019 presidential election situation. In fact, the making of this account, claimed as a way to reduce conflicts in the community because of the hot 2019 presidential election. In addition, the account was formed as entertainment for the people of Indonesia (Subagja, 2019). Nurhadi in the BBC.com video, which was reposted by the Instagram account @nurhadi.aldo. official2019, conveyed the intent of forming a fictitious presidential and vice presidential candidate: unpleasant but that, with the presence of presidential candidate number 1o can unite the citizens of Indonesia.

Besides aiming to entertain, nurhadi aldo's campaign content also aims to criticize the government, politicians and the people. One of the Success Team nurhadi_aldo said to BBC.com as quoted by tirto.id:

"When Nurhadi came out in the form of jokes, there was a message for the community. There is much we can criticize, there are governments, politicians, rather than fighting with

\section{fellow people" (Khalika, 2019).}

The Success Team, the creator of the nurhadi_aldo account, hopes that the people will not be easily divided by political elites during the presidential election. Like the participants in the official presidential election, this pair was promoted by the party. But the party that carries it is also fictitious, namely the Party for the Need for Faith (PUKI). In addition, like the official pair of presidential and vice presidential candidates, this alternative pair also offers a visionmission and program, and the name of the coalition. Tronjal Coalition Tronjol Maha Asik became the name of the couple's coalition with the hashtag campaign \#MCQUEEN \#YAQUEEN (read: \#more \#sure). Whereas the official presidential and vice presidential tagline is 'Adil Makmur with Prabowo Sandi' which was later revised on January 9, 2019 to 'Indonesia Win' for the Prabowo-Sandi pair, and 'Jokowi-Amin Indonesia Forward', 'White Is Us' for the campaign slogan Jokowi and Ma'ruf Amin.

In an effort to show Nurhadi Aldo's vision and mission that is different from the official presidential and vice presidential candidates, in his writing juxtaposed with the vision and mission of the two pairs of real presidential and vice presidential candidates. Coupled with displaying pictures of the bearers of each pair of official and fictitious vice presidential candidates.

In Nurhadi and Aldo's vision the object of the satire was confirmed. The term 'ruling class' is emphasized in their vision as political problem-making actors. Not even halfhearted in delivering his message without using metaphorical languages. Nurhadi and Aldo dense and clearly wrote the vision "The realization of a just, strong, intelligent, and educated society in addressing the political problemscreated by theruling class." Theterm 'ruling class' also reappears in the description of their mission. On point 6, they explained their mission of reducing the grip of the ruling / government class to the common people. The term 'ruling class' is italicized with the word 'government', meaning that the actor can be the ruling class or the government. 
Both are considered as actors who oppress small people, not as they should be present in the middle of small people. Following are the elaborations of Nurhadi and Aldo's mission: Building a strong economy based on food security and the welfare of workers and peasants; educating workers and peasants to become a new political force in Indonesia; organizing workers and peasants; creating unemployment as employment; bringing social justice to all Indonesian people; reducing the grip of the ruling class/ government to the small people.

\section{f. Political Satire on Facebook}

The 2019 Movement to Change the President through the \#2019GantiPresiden was initiated by Mardani Ali Sera, Secretary General of the Prosperous Justice Party, Eggi Sudjana, and Eno Warisman. The idea was explained by Mardani after attending the 'Indonesia Lawyers Club' event in conventional media, tvONE. According to him, this movement as a 'wake up call' for Muslims in Indonesia, by warning that the 2019 elections are in sight and it's time to find a better leader for Indonesia. The idea was then campaigned to various regions with the aim being that the ideas spread to the network so that a joint campaign "2019 Change President" would appear (Kresna, 2019).

Around April 9-10, 2018, Hashtag \#2019GantiPresiden became a trending topic on Twitter (Gunawan, 2018). In other new media (Facebook) leading up to the 2019 presidential election, an account called 2019 presidential candidate appears. The account already has 24,780 followers with a total of 'likes' 24,506. This account is actively posting content in video, comic, meme packaging related to the presidential election.

After 2019 presidential election, 2019 GANTIPRESIDEN account is still actively posting. One of them is seen in figure 6. The post is a screenshot of the @JokoWidodo Twitter conversation accompanied by a caption. The written caption emphasizes the effort to realize joint motion. As with the nature of new media, direct comments on posts can occur immediately. Seen in the figure 6 get comments from netizens. The comments that emerged were also debates among netizens. Sadly, swearwordsappeared, accusations in the comments column.

If traced from each post, the 2019 change of president is not the same goal as stated by Mardani Ali Sera for a wake up call 'for Muslims in Indonesia, by warning that the 2019 elections are in sight and it's time to find a better leader for Indonesia. However, each post actually leads to the efforts of President Joko Widodo's delegitimacy.

The 2019 hashtag for president will not only live in new media, but also be a real movement. Supporters of the 2019 hashtag for president change took to the streets on a car free day on April 29, 2018 around the HI roundabout to raise voluntary funds by selling t-shirts reading \#2019GantiPresiden and efforts to show their existence. The coordinator of the movement Iwan Firdaus voiced yells, "This movement is politically gaining support from political parties." Furthermore, the group with T-shirt \#2019GantiPresiden had intimidated supporters of Jokowi's supporters in the \#DiaSibukKerja who also held events at the HI roundabout. Susi Ferawati's confession was a victim of intimidation that, "it was made fun of by a tadpole, rice packets, you don't have money. Because we used the \#DiaSibukKerja tagline T-shirt, we were told, 'You always work, you're like a slave” (Kresna, 2019).

\section{CONCLUSION}

From the exploration of ideas and the packaging of political communication and satire from the three case studies above, the reseacher finds several essential points. First, The 2019 presidential election gave rise to ideas of political communication and spontaneous satire about what they saw, what they felt, and their experiences relating to the global world. The satirical communication conducted by skinnyindonesiaz 4 is an example of the interaction between universal values and the country's political situation. Second, each informant account translates their ideas from the political situation that occurred during the presidential election, the strategy of the two winning teams, and their 
supporters' actions on social media. Thirth, there are two categories of message objectives delivered, namely reducing the effects of polarization that arise and, at the same time criticizing the government, politicians, and including netizens who are fans of supporters of each pair of candidates. The content of nurhadi_aldo's creation raises concerns for activists and the public because it is considered vulgar, sexist, and pornographic. In packaging ideas, they have a different way. Nurhadi_aldo expressed his opinion in the form of sentences, memes, and quotes from presidential candidates who were ridiculed roughly for insinuating the candidates. Unlike the case with Skinnyindonesia24, who uploaded Prabowo vs. rap battle videos. Jokowi in 2014 and 2019 in the form of song lyrics with a more elegant choice of words. Political communication messages on the \#2019GantiPresiden Facebook account tend to use critical narratives and memes that critics incumbent candidates. The three social media accounts use a hashtag to spread more widely to influence people's political behavior and attitude. Finally, this research does not yet discuss the meaning of the satirical message, so the researcher recommends continuing analysis of the picture and texts on social media platforms that uploaded satire. By doing this analysis, we expect to get more explanation from another perspective of the message.

\section{ACKNOWLEDGEMENT}

I thank to Dean of Social and Political Sciences and Research \& Community Service Board (BPPM) of FISIP Universitas Brawijaya for their research grant. I would also like to acknowledge the Association of Indonesia Communication Scholars (ISKI) and also the editorial team of Informasi journal for their constructive feedback.

\section{REFERENCES}

Adytia, I. (2019, 10 April). Rap Batle Prabowo - Jokowi Tranding di YouTube. Accessed fromhttps://krjogja.com/web/news/ read/96376/Rap_Batle_Prabowo_ Jokowi_Tranding_di_youTube., Jun 23, 2019.
Andovi Da Lopez. (2019, 24April). Bedah Lirik Prabowo VS Jokowi Part2. Accessed from https://www.youtube.com/ watch?v=prSN3 $\mathrm{P}_{5}$ fboo, September 12, 2019

Arifin, A. (2011). Komunikasi politik: filsafatparadigma-teori-tujuan-strategi dan komunikasi politik Indonesia, Graha Ilmu: Yogyakarta.

Bessant, J. (2016). New politics and satire: The Euro financial crisis and the one fingersalute. Information, Communication $\mathcal{E}$ Society, 20:7, 1057-1072, DOI: 10.1080/1369118X.2016.1206138.

Boukes, M. (2019) Agenda-Setting with satire: how political satire increased TTIP's saliency on the public, Media, and Political Agenda, Political Communication, 36:3, 426-451, DOI: 10.1080/10584609.2018.1498816

Bode, L \& Vraga, E.K. (2018) Studying politics across media, Political Communication, 35:1, 1-7, DOI: 10.1080/10584609.2017.1334730

Bradshaw, S., Howard, P.N., Kollanyi, B. \& Neudert, L. (2020) Sourcing and automation of political news and information over social media in the United States, 2016-2018, Political Communication, 37:2, 173-193, DOI: 10.1080/10584609.2019.1663322

Cameron, K. (1993), Humour and History, in Humour and History, K. Cameron (ed.), England: Intellect, 5-9.

Cutbirth, J. H. (2011). Satire as Journalism: The Daily Show and American Politics at the Turn of the Twenty-First Century. Columbia University. University Columbia

Efriza, \& Indrawan, J. (2018). Komunikasi politik pemahaman secara teoritis dan empiris. Malang: Intrans Publishing.

Gunawan, B. (2018, April 30). Propaganda politik melalui 'hashtag' media sosial, Detik news. Accessed from https:// news.detik.com/kolom/d-3997572/ propaganda-politik-melalui-hashtag- 
media-sosial, 12 September 2019.

Jenkins, H., Ford, S., \& Green, J. (2013), Spreadable media: creating value and meaning in a networked culture, New York: New York University Press.

Jovial Da Lopez. (2019, 11 April). Interview on the show "Rosi - Adu Seru Prabowo Vs Jokowi”. Accessed from https://www.youtube.com/ watch?v=toZFXQdC9mM, 8 Agustus 2019 .

Juniarto, D. (2019, July 26) Amos Yee dinyatakan bersalah. Accessed from http://id.safenetvoice.org/2015/o5/ amos-yee-dinyatakan-bersalah/, $\quad 1$ Agustus 2019.

Jamieson, K. H., \& Kenski, K. (2014). Political communication: then, now and beyond, in Oxford Handbook of Political Communication, K. Kenski \& K. H. Jamieson (eds.), New York: Oxford University, doi:10.1093/ oxfordhb/9780199793471.013.77

Khalika, N.N. (2019, July 07). Nurhadi-Aldo dan meme sebagai saluran kritik dan frustasi kreator. Accessed from https:// tirto.id/nurhadi-aldo-dan-memesebagai-saluran-kritik-frustrasikreator-ddM3, 10 September 2019.

Kresna, M. (2019, May 02). Para politikus di belakang layar gerakan '2019GantiPresiden. Accessed from https://tirto.id/para-politikus-dibelakang-layar-gerakan-2019-gantipresiden-cJKx, 9 September 2019.

Louw, P. E. (2007). The media and political process. New York: SAGE Publications Ltd.

Marison, W. (2019, July 26). Ratna Sarumpaet Divonis Dua Tahun Penjara. Accessed from https://megapolitan.kompas. $\mathrm{com} / \mathrm{read} / 2019 / \mathrm{o} / 11 / 16561791 / \mathrm{ratna}-$ sarumpaet-divonis-dua-tahun-penjara

Mengecam Pelanggaran Hak Digital Terbaru di Singapura. (2019 January 10). Accessed from http://id.safenetvoice. org/2019/o1/safenet-mengecam- pelanggaran-hak-digital-terbaru-disingapura/, 20 Maret 2019.

Neuman, W. L. (2013). Social research methods: qualitative and quantitative approaches. $7^{\text {th }}$ ed., Boston: Pearson Education.

Neuman, W.R. (1991), The future of the mass audience, Cambridge: Cambridge University Press.

P, A.N (2016), Ekonomi politik media: pada pemberitaan menjelang pemilihan gubernur Banten 2017 oleh Radar Banten dan Baraya TV, Informasi, 46:2, 155-168, doi.org/10.21831/informasi. v46i2.12247.

Plevriti, V. (2013). Satirical User-Generated memes as an effective source of political criticism, extending debate and enhacing civic engagement. The University of Warwick: Centre for Cultural Policy Studies.

Punnett, I. C. \& Russomanno, J. (2018) "Pacifica" at Forty: Restraint on satire in America, its impact on broadcast journalism, and justice brennan's prophetic dissent, Journal of Radio $\mathcal{E}$ Audio Media, 25:2, 321-336, DOI: 10.1080/19376529.2018.1479142

Reilly, I. (2013). From critique to mobilization: the yes men and the utopian politics of satirical fake news. International Journal of Communication, 7:1, 12431264.

Sampedro, V. \& Avidad, M.M. (2018), The digital public sphere: an alternative and counterhegemonic space? The case of Spain, International Journal of Communication, 18, 23-44.

Sapienza, Z. S., Iyer, N., \& Veenstra, A. S. (2015). Reading Lasswell's model of communication backward: three scholarly misconceptions. Mass Communication and Society. 18:5, 599622.doi:10.1080/15205436.2015.1063666.

Sidwell, K. (2009). Aristophanes the democrat: The politics of satirical comedy during the peloponnesian war. 
New York: Cambridge University Press. doi:10.1017/CBO9780511657382.

Subagja, I. (2019, January 14). Akun NurhadiAldo menghilang dari Instagram, tim sukses buka suara. Accessed from https://kumparan.com/ kumparannews/akun-nurhadi-aldomenghilang-dari-instagram-timsesbuka-suara-1547453004727579979

Tapsell, R. (2017). Kuasa media di Indonesia. (W. P. Utomo, Penerj.). Banten: Marjin Kiri.
Utomo, W. (2015). Menertawakan politik: anak muda, satire dan parodi dalam situs mojok.co. Jurnal Studi Pemuda, 4:1, 190-205. doi: 10.22146/ studipemudaugm.36729.

Van-Dijk, T. A. (1993). Principles of critical discourse analysis. Discourse $\mathcal{E}$ Society, 4:2, 249-283. doi:10.1177/0957926593004002006

Van Dijk, T. A. (2006). Discourse and manipulation. Discourse E Society, 17:3, 359-383. doi:10.1177/0957926506060250 